\title{
Selection for Durable Resistance to Leaf Rust using Test- Crosses on IAPAR-59 and Tupi IAC 1669-33 cultivars of Coffea arabica
}

\author{
Gustavo Hiroshi Sera*, Tumoru Sera, Dhalton Shiguer Ito, José Alves de Azevedo, João \\ Siqueira da Mata, Deisy Saori Doi and Claudionor Ribeiro Filho \\ Instituto Agronômico do Paraná; Área de Melhoramento e Genética Vegetal; Rod. Celso Garcia Cid; Km 375; \\ C.P.: 481; 86.001-970; gustavosera@uol.com.br; tsera@iapar.br; Londrina - PR - Brasil
}

\begin{abstract}
The aim of this study was to identify plants of the IAPAR-59 and Tupi IAC 1669-33 coffee cultivars with less defeated resistance genes by the rust races present at IAPAR (Londrina, Paraná State, Brazil) using test-crosses. Eighteen test-crosses derived from hybridizations between 'IAPAR-59' or 'Tupi IAC 1669-33' with susceptible coffee to the rust disease were evaluated. Six hybrids were used as susceptible standards originated from hybridizations between two susceptible coffee plants. Many parental plants of the 'IAPAR-59' and 'Tupi IAC 166933' presented more defeated resistance genes against rust races present at IAPAR than others of these cultivars or the genes were in heterozygous, because of segregant susceptible plants observed in some test-crosses. The testcrosses were very efficient to identify plants with less defeated resistance genes to the $\underline{H}$. vastatrix. Coffee plants considered resistants would must be made test-crosses to verify which plants presented less and/or more defeated genes in homozygous.
\end{abstract}

Key words: Hemileia vastatrix, breeding, coffee crop, rust races, SH genes

\section{INTRODUCTION}

The most important disease of Coffea arabica $\mathrm{L}$. is coffee leaf rust, caused by Hemileia vastatrix Berk. et $\mathrm{Br}$, because the majority of the cultivars are susceptible. According to Matiello et al. (2002), in Brazil, $95 \%$ of the arabica coffee cultivated area is composed by cultivars of Mundo Novo and Catuaí germplasms, both susceptible to the coffee leaf rust. The remained area is constituted by resistant cultivars like 'IAPAR-59', 'Tupi IAC 1669-33' and 'Obatã IAC 1669-20'. The chemical control for leaf rust is efficient, but it demands expenses with fungicides. The deficient control leads to the bad nourishment and defoliation at winter months, resulting in coffee trees predisposed for frost, because deficient plants freeze more quickly (Sera and Guerreiro, 1995). The defoliation, before the floral induction, reduces the flowering and, during the fruits development, leads to the formation of small grains and badly nourished, affecting significantly the yield and the quality (Godoy et al., 1997). Coffee leaf rust causes decreases in the yield that varies from 35 to $50 \%$, depending on the cultivar susceptibility, humidity, plant yield and nutritional state (Zambolim et al., 1997).

The use of resistant cultivars is the most efficient, economic and ecologically correct control for this

${ }^{*}$ Author for correspondence 
disease. Many resistant cultivars to the rust disease already exist with $\mathrm{S}_{\mathrm{H}} 5, \mathrm{~S}_{\mathrm{H}} 6, \mathrm{~S}_{\mathrm{H}} 7, \mathrm{~S}_{\mathrm{H}} 8, \mathrm{~S}_{\mathrm{H}} 9$ and $\mathrm{S}_{\mathrm{H}}$ ? resistance genes like coffees of the Sarchimor and Catimor germplasms. These genes originated from C. canephora, one of the genitors of the "Híbrido de Timor" ("HDT") and other interspecific hybrids like the "Icatu". $\mathrm{S}_{\mathrm{H}} 1, \mathrm{~S}_{\mathrm{H}} 2, \mathrm{~S}_{\mathrm{H}} 4$ and $\mathrm{S}_{\mathrm{H}} 5$ genes, which confer resistance to some $H$. vastatrix physiological races and were detected in pure arabica coffee accesses originated from Ethiopia. $\mathrm{S}_{\mathrm{H}} 3$ gene supposedly is derived from $C$. liberica (Bettencourt and Rodrigues Jr., 1988). Bettencourt (1981) reported that the resistance factors known to rust are $S_{\mathrm{H}} 1$ to $S_{\mathrm{H}} 9$ more $S_{\mathrm{H}}$ ?, contrasting with the corresponding $H$. vastatrix virulence factors $\mathrm{v} 1$ to v9 more v?. The existence of other resistance genes $\left(\mathrm{S}_{\mathrm{H}}\right.$ ?) in derivatives of "HDT' and other interspecific hybrids have been confirmed due to defeated resistance by new rust races in some of these genotypes (Rodrigues Jr. et al., 2000).

Studies carried out in India (Mayne, 1932, 1935 apud Varzea et al., 2002) and in Portugal (Varzea et al, 1989; Rodrigues Jr. et al., 1993), differentiated forty physiological races of $H$. vastatrix, isolated from rust sampled on coffee trees originated from different regions. Six others new races were being characterized at Centro de Investigação das Ferrugens do Cafeeiro (CIFC) in Oeiras, Portugal (Varzea et al., 2002). The defeated resistance by new rust races in varieties of Catimor germplasm was observed. Probably, the resistance defeat in coffees of Icatu germplasms also occurred. In the case of the
"Sarchimor" certain genotypes continued to present complete resistance for the new physiological races and the same occurred in some plants of the Colombia cultivar of germplasm Catimor (Varzea et al., 2002). The main cause of variation in $H$. vastatrix has been related with genetic mutations (Varzea et al., 2002). To control the high capacity of this fungus to defeat the resistance, it would be necessary to develop the cultivars with many $S_{H}$ genes simultaneously aiming the durable resistance. The aim of this study was to identify coffee plants of the IAPAR59 and Tupi IAC 1669-33 cultivars with less defeated resistance genes by the leaf rust using test-crosses.

\section{MATERIAL AND METHODS}

Two field assays, E0008 and E0102, respectively, were carried out in December 2000 and March 2001 on $2.5 \mathrm{~m} \times 0.5 \mathrm{~m}$ plots. The altitude is 585 $\mathrm{m}$, the annual average precipitation is $1610 \mathrm{~mm}$, annual average temperature of $20.8^{\circ} \mathrm{C}$ and relative humidity of air is $71 \%$. In these assays no have chemical control for rust disease were made.

The evaluation of field condition resistance was performed on local leaf rust population on coffee with 25 months (E0008) and 28 months (E0102) after planting.

The resistance to $H$. vastatrix by natural high infection condition was used a score scale varying from 1 to 5 (Table 1).

Table 1 - Score scale used in the field evaluation of the resistance to local rust races at IAPAR (Londrina, PR, Brazil)

\begin{tabular}{cl}
\hline Scores & \multicolumn{1}{c}{ Description } \\
\hline 1 & Plants without chlorotic spots on the leaves. \\
2 & Leaves with few chlorotic spots $(1$ to 5 spots $)$ without spores. \\
3 & $\begin{array}{l}\text { Leaves with few chlorotic spots }(1 \text { to } 5 \text { spots }) \text { with spores and the injured leaf between } \\
1 \% \text { and } 9 \% .\end{array}$ \\
& $\begin{array}{l}\text { Number of spots with spores on leaves between } 6 \text { and } 25 \text { and injured leaf between } 10 \\
4\end{array}$ \\
& Number of spots with spores on leaves more than 25 and injured leaf more than $35 \%$. \\
\hline
\end{tabular}

Eighteen test-crosses were evaluated derived from the hybridizations between some plants of the IAPAR 59 and Tupi IAC 1669-33 cultivars with susceptible coffee trees to rust. Six hybrids were used as susceptible standards originated from hybridizations of two susceptible parentals, being three of the E0008 and three of the E0102 (Table
2). For E0008, the pollen of several plants of the 'IAPAR 59 UBS' and 'Tupi IAC 1669-33 UBS' were used for test-crosses. For E0102, 'Tupi IAC 1669-33 III-3', 'Tupi IAC 1669-33 II-7' and 'Tupi IAC 1669-33 I-10' were individual plants of the 'Tupi IAC 1669-33 UBS' population. The genotypes 'IAPAR-59 e9702 III-1-9' and 
'IAPAR-59 e9701 I-1-5' were individual plants of the 'IAPAR-59 e9702' and 'IAPAR-59 e9701' populations, respectively. The susceptible genotypes named "Et. $S_{\mathrm{H}} 1$ x Catuaî" I-1, "Et. $\mathrm{S}_{\mathrm{H}} 1$ x Catuaî" I-3 and "Et. $S_{H} 1$ x Catuaî́" I-11", used in the test-crosses at E0102 assay, were individual plants originated from $\mathrm{F}_{2}$ population of " $C$. arabica accession from Ethiopia carrying $\mathrm{S}_{\mathrm{H}} 1$ gene" x "Catuaî". 'IPR-100' derived from "Catuaí $\mathrm{S}_{\mathrm{H}} 2, \mathrm{~S}_{\mathrm{H}} 3$ " but, probably, didn't have the $\mathrm{S}_{\mathrm{H}} 2$ and/ or $\mathrm{S}_{\mathrm{H}} 3$ gene. The origin of "Catucaí b. E9502" is unknown, but this genotype is susceptible to rust. The genotypes "IAPAR-89203 III-16-3", "IAPAR-89203 I-4-11" and "IAPAR-89203 V-2113" were individual plants derived from $\mathrm{F}_{2}$ population of "IAPAR-89203" ('IAPAR-59' x "Mundo Novo").

The percentage of susceptible plants of the $F_{1}$ hybrids was used as parameter to identify plants of 'IAPAR-59' and 'Tupi IAC 1669-33' with less defeated resistance genes by the local rust races population. Plants with scores 1 and 2 of rust incidence were considered resistants and with scores 3, 4 and 5 as susceptible ones. The number of assessed plants and origin of each test-cross, with respective assays and identification number of the treatments are presented in Table 2 .

\section{RESULTS AND DISCUSSION}

The average rust score incidence and percentage of susceptible plants are presented in Table 2. Except the standard ("Et. $\mathrm{S}_{\mathrm{H}} 1$ " x "Catuaî" I-11) x 'Icatu IAC-3282', which presented $94.12 \%$ of susceptible plants, all the other standards presented $100 \%$ of susceptible plants. This indicated that the standard hybrids were goods for comparisons. The hybrids of the E0102 assay, where one of the parentals used was the 'IAPAR 59 III-1-9' or the 'IAPAR 59 I-1-5', many susceptible plants to the rust were observed. The average of susceptible plants of five hybrids was $60.77 \%$ when 'IAPAR59 III-1-9' was used as parental, while that for the 'IAPAR-59 I-1-5', the average was $9.72 \%$, indicating that this presented less defeated $\mathrm{S}_{\mathrm{H}}$ genes and/ or more resistance genes in homozygous to local population of leaf rust.

It was possible that the 'IAPAR-59 UBS' population presented more resistance genes not defeated than plants of the 'IAPAR-59 e9701' and 'IAPAR-59 e9702' populations. This was because in two test-crosses accomplished at E0008, $100 \%$ of resistant plants were observed when plants of 'IAPAR-59 UBS' were used as pollinators. All the plants of the test-crosses where the plants 'Tupi IAC 1669-33 III-3' and 'Tupi IAC 1669-33 II-7' were used, presented resistance to $H$. vastatrix. Thus, these two plants had less defeated resistance genes and/ or more genes were in homozygous than the plant 'Tupi IAC 1669-33 I-10', because in the test-cross 'Tupi IAC 1669-33 I-10' x "Pacas" were observed $70.37 \%$ of susceptible plants.

At E0008, the average of susceptible plants of the four test-crosses was $9 \%$ when the 'Tupi IAC 1669-33 UBS' population was used as pollinator, while the average of the test-crosses with the 'IAPAR-59 UBS' population was $0 \%$. This indicated that the plants of 'Tupi IAC 1669-33 UBS' carried less not defeated resistance genes than plants of the 'IAPAR-59 UBS'.

The results presented in Table 2 indicated that many plants of the 'IAPAR-59' and 'Tupi IAC 1669-33' had more defeated resistance genes than others of these cultivars or the genes were in heterozygous. Probably, these plants of the 'IAPAR-59' and 'Tupi IAC 1669-33' didn't carry $\mathrm{S}_{\mathrm{H}}$ ? gene or others $\mathrm{S}_{\mathrm{H}}$ genes originated from "Híbrido de Timor" CIFC 832-2. Thus, it was necessary to select in these cultivars the plants with more resistance not defeated genes like the plants 'Tupi IAC 1669-33 III-3' and 'Tupi IAC 1669-33 II-7', which presented $100 \%$ of resistant plants in the test-crosses. These two plants and plants of 'IAPAR-59 UBS' population would be used in hybridizations with coffee carrying $\mathrm{S}_{\mathrm{H}} 3$ gene aiming to obtain more durable resistance to the rust disease.

It could be concluded that the test-crosses were efficient and even in plants apparently resistant to all the world physiological rust races like IAPAR59 and Tupi IAC 1669-33 cultivars, presenting complete resistance for more than 30 years, segregation in some plants were observed.

Test crosses should also be made for coffee considered resistants such as 'IAPAR-59', 'Tupi IAC 1669-33', 'Obatã IAC 1669-20', 'Colombia', 'Siriema', 'Oeiras MG 6851', 'Paraíso MG H4191', Catucaí's cultivars and others which presented less defeated resistance genes. After this analysis, mother plants without susceptible segregants in progenies derived from test crosses could be used as pollinator plants or mother plants for hybridizations with coffee trees carrying genes like $\mathrm{S}_{\mathrm{H}} 3$ aiming at more durable resistance. The resistance genes $S_{H} 1, S_{H} 2$ and $S_{H} 4$, alone or in 
combinations, didn't provid durable resistance (Eskes, 1983).

The $\mathrm{S}_{\mathrm{H}} 3$ gene and certain genes of $C$. canephora like of the "Híbrido de Timor" and "Icatu" could be more efficient to get durable resistance, especially when used in combination with complete resistance (Bergamin-Filho, 1976; Eskes, 1983). Seed fields would have to be made starting from these plants with less broken resistance genes identified by test-crosses. The extensive planting of coffee cultivars with many resistance genes like genotypes derivatives of the group A (resistant to all the races), that presented susceptible plants in the test-crosses must be avoided. This would be because it was possible that these remained only one $S_{H}$ gene to be defeated. Thus, this would facilitate the formation of new races, like in India, where the race XXXIX was identified.

Table 2 - Resistance to the rust disease in coffee hybrids with respective mean score, percentage of susceptible plants (\% Sus. plants), number of assessed plants ( $\mathrm{n}^{\circ} \mathrm{pl}$.), experiment and treatment number (Treat $\mathrm{n}^{\circ}$ ) (IAPAR, Londrina, Paraná state, Brazil).

\begin{tabular}{|c|c|c|c|c|c|}
\hline Experiments & $\begin{array}{c}\text { Treat } \\
\text { n }^{\circ}\end{array}$ & Hybrids $^{(1)}$ & $\begin{array}{l}\text { Mean } \\
\text { score }{ }^{(2)}\end{array}$ & $\begin{array}{c}\text { \% Sus. } \\
\text { plants } \\
(3)\end{array}$ & $\overline{\mathbf{n}^{0} \mathrm{pl}}$ \\
\hline \multirow{9}{*}{ E0008 } & 9 & “Catucaí b. E9502” x 'IAPAR-59 UBS' & 1.00 & 0.00 & 23 \\
\hline & 10 & “Catucaí b. E9502” x ‘Tupi IAC 1669-33 UBS’ & 1.22 & 8.70 & 23 \\
\hline & 14 & 'Mundo Novo IAC 376-4' x 'Tupi IAC 1669-33 UBS’ & 2.29 & 25.00 & 24 \\
\hline & 15 & 'Catuaí Vermelho IAC 81' x 'IAPAR-59 UBS' & 1.00 & 0.00 & 24 \\
\hline & 16 & 'Catuaí V. IAC 81' x ‘Tupi IAC 1669-33 UBS' & 1.18 & 2.27 & 44 \\
\hline & 17 & 'Icatu Precoce IAC 3282' x ‘Tupi IAC 1669-33 UBS' & 1.32 & 0.00 & 19 \\
\hline & 28 & * ‘Mundo Novo IAC 376-4' x “IAPAR-89203 III-16-3” & 4.67 & 100.00 & 6 \\
\hline & 29 & * ‘Mundo Novo IAC 376-4’ x “IAPAR-89203 I-4-11” & 3.75 & 100.00 & 4 \\
\hline & 30 & * ‘Mundo Novo IAC 376-4' x “IAPAR-89203 V-21-13” & 3.83 & 100.00 & 6 \\
\hline \multirow{14}{*}{ E0102 } & 56 & $\left(\mathbf{F}_{\mathbf{2}}\right.$ “Et. $\mathbf{S}_{\mathrm{H}} \mathbf{1}$ ” x “Catuaî” I-1) x ‘IAPAR-59 e9702 III-1-9’ & 3.43 & 90.00 & 20 \\
\hline & 57 & $\left(\mathbf{F}_{\mathbf{2}}\right.$ “Et. $\mathbf{S}_{\mathbf{H}} \mathbf{1}$ ” x “Catuaí” I-3) x ‘IAPAR-59 e9702 III-1-9’ & 2.29 & 35.48 & 31 \\
\hline & 58 & $\left(\mathbf{F}_{\mathbf{2}}\right.$ “Et. $\mathbf{S}_{\mathbf{H}} \mathbf{1}$ ” x “Catuaí” I-11) x ‘IAPAR-59 e9702 III-1-9' & 2.95 & 55.00 & 20 \\
\hline & 59 & $\left(\mathbf{F}_{\mathbf{2}}\right.$ "Et. $\mathbf{S}_{\mathbf{H}} \mathbf{1}$ ” x “Catuaî" I-1) x 'Tupi IAC 1669-33 III-3' & 1.00 & 0.00 & 18 \\
\hline & 60 & $\left(\mathbf{F}_{\mathbf{2}}\right.$ "Et. $\mathbf{S}_{\mathbf{H}} \mathbf{1}$ ” x “Catuaî" I-3) x 'Tupi IAC 1669-33 III-3' & 1.26 & 0.00 & 31 \\
\hline & 65 & 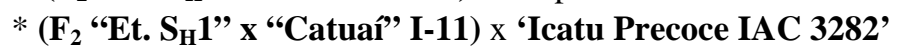 & 4.82 & 94.12 & 17 \\
\hline & 67 & * $\left(\mathbf{F}_{2}\right.$ “Et. $\mathbf{S}_{\mathrm{H}} \mathbf{1}$ ” x “Catuaî” I-3) x “Catucaí b. E9502” & 4.29 & 100.00 & 17 \\
\hline & 82 & * ‘Catuaí V. IAC-81’ x “Catuaí semperflorens” & 4.50 & 100.00 & 12 \\
\hline & 91 & ‘IPR 100’ x ‘IAPAR-59 e9702 III-1-9’ & 2.56 & 44.44 & 9 \\
\hline & 92 & 'IPR 100’ x ‘Tupi IAC 1669-33 III-3’ & 1.08 & 0.00 & 13 \\
\hline & 97 & ‘Tupi IAC 1669-33 I-10’ x “Pacas” & 3.04 & 70.37 & 27 \\
\hline & 98 & ‘Tupi IAC 1669-33 II-7’ x “Pacas” & 1.00 & 0.00 & 15 \\
\hline & 99 & ‘IAPAR-59 e9702 III-1-9’ x “Pacas” & 3.16 & 78.95 & 19 \\
\hline & 100 & 'IAPAR-59 e9701 I-1-5’ x “Pacas" & 1.86 & 9.72 & 72 \\
\hline
\end{tabular}

${ }^{(1)}$ Et. $\mathrm{S}_{\mathrm{H}} 1=$ "C . arabica accession from Ethiopia carrying $\mathrm{S}_{\mathrm{H}} 1$ gene"; Catuaí V. = Catuaí Vermelho.

(2) Score scale used in the field evaluation of the resistance to local rust races: $1=$ Plants without chlorotic spots on the leaves; $5=$ number of spots with spores on leaves more than 25 and injured leaf more than $35 \%$.

${ }^{(3)}$ Plants with scores 3, 4 and 5 of rust incidence were considered resistants.

* Susceptible standards to local rust $(H$. vastatrix) population.

The susceptible genotypes to local rust (H. vastatrix) population are presented in bold.

This study also indicated that IAPAR could have new rust races that had defeated the $\mathrm{S}_{\mathrm{H}} 5, \mathrm{~S}_{\mathrm{H}} 6, \mathrm{~S}_{\mathrm{H}} 7$, $\mathrm{S}_{\mathrm{H}} 8$ and $\mathrm{S}_{\mathrm{H}} 9$ genes, alone or in combination, like the race XXXIX with seven virulence genes (v2, $4,5,6,7,8$ and 9) or race XXIX with genes v5, 6 , 7,8 and 9 . It was possible that only the $\mathrm{S}_{\mathrm{H}}$ ? resistance gene of the "Sarchimor" wasn't defeated. Leaf samples with sporulation of these susceptible segregant plants could be sent to the CIFC to verify the appearance of new rust races. Clones of plants of 'IAPAR-59' and 'Tupi IAC 1669-33' that presented susceptibility to the rust must be sent to the CIFC. Therefore, it was possible to find new coffee differentials in these segregant populations. Varzea et al. (2002) reported that differential plants originated from 
"Catimor" and "Sarchimor" did not exist, making it difficult the characterization of the virulence genotypes of some rust isolated originated from these germplasms.

\section{CONCLUSIONS}

- Many plants of the 'IAPAR-59' and 'Tupi IAC 1669-33' presented more defeated resistance genes by the rust races present at IAPAR than others of these cultivars or the genes were in heterozygous that ought to be avoided to use in future crossings.

- The test-crosses were very efficient to select plants with less defeated resistance genes by the $H$. vastatrix.

- In coffee plants considered resistants testcrosses must be made to verify which plants presented less defeated resistance genes and/or more genes in homozygous before crossing aiming durable resistance.

- The plants 'Tupi IAC 1669-33 III-3', 'Tupi IAC 1669-33 II-7' and plants of 'IAPAR-59 UBS' presented less defeated resistance genes and/ or resistance genes in homozygous to rust races present at IAPAR than others of these cultivars.

\section{ACKNOWLEDGEMENTS}

The authors thank the Instituto Agronômico do Paraná (IAPAR) and the Consórcio Brasileiro de Pesquisa e Desenvolvimento do Café (CBPandD Café).

\section{RESUMO}

A ferrugem é uma das principais doenças do café. O objetivo deste trabalho foi identificar plantas das cultivares IAPAR-59 e Tupi IAC 1669-33 com menos genes de resistência quebrados às raças de ferrugem presentes no IAPAR (Londrina, Paraná, Brasil) através de cruzamentos testes. Foram avaliados 18 cruzamentos testes derivados dos cruzamentos de 'IAPAR-59' ou 'Tupi IAC 166933' com cafeeiros suscetíveis à ferrugem. Seis híbridos foram usados como testemunhas suscetíveis derivados do cruzamento de dois cafeeiros suscetíveis. Muitas plantas da 'IAPAR-
59' e 'Tupi IAC 1669-33' apresentam mais genes de resistência quebrados pelas raças de ferrugem presentes no IAPAR do que outras dessas cultivares ou os genes estão em heterozigoze, pois foram observadas muitas plantas segregantes suscetíveis em alguns cruzamentos testes. Os cruzamentos testes são muito eficientes para selecionar plantas com menos genes de resistência à ferrugem quebrados. Em cafeeiros de cultivares considerados resistentes deveriam ser feitos cruzamentos testes para verificar quais plantas apresentam menos genes de resistência quebrados ou mais genes em homozigoze.

\section{REFERENCES}

Bergamin-Filho, A. (1976), Possibilidades do emprego da resistência vertical no melhoramento do cafeeiro contra Hemileia vastatrix. Summa Phytopathol., 2, 103.

Bettencourt, A. J. (1981), Melhoramento genético do cafeeiro: transferência de factores de resistência à Hemileia vastatrix Berk. and Br. para as principais cultivares de Coffea arabica L. Lisboa: Junta de investigações científicas do Ultramar/Centro de Investigação das Ferrugens do cafeeiro, Oeiras. 93 p.

Bettencourt, A. J.; Rodrigues JR., C. J. (1988), Principles and practice of coffee breeding for resistance to rust and other diseases. In: Clarck, R.J.; MACRAE, R. (Eds.). Coffee, v.4 Agronomy. Elseviers Applied Science, p.199-235.

Eskes, A. B. (1983), Incomplete resistance to coffee leaf rust (Hemileia vastatrix). $140 \mathrm{f}$. Doctoral thesis, Agricultural University of Wageningen, The Netherlands.

Godoy, C. V.; Bergamim Filho, A.; Salgado, C. L. (1997), Doenças do cafeeiro (Coffea arabica L.). In: Kimati, H.; Amorim, L.; Bergamim Filho, A.; Camargo, L. E. A.; Rezende, J. M. (Eds.). Manual de Fitopatologia. 3. ed. v. 2. São Paulo: Agronômica Ceres. cap. 17. p. 184 - 200.

Matiello, J. B., Santinato, R., Garcia, A. W. R., Almeida, S. R., Fernandes, D. R. (2002), Cultura de café no Brasil - Novo manual de recomendações. Mapa/Procafé Rio de Janeiro - RJ e Varginha - MG. p. 54-76.

Rodrigues Jr., C. J.; Várzea, V. M. P.; Godinho, I. L.; Palma, S.; Rato, R. C. (1993), New physiologic races of Hemileia vastatrix. In: International Scientific Colloquium On Coffee, 15., 1993, Montpellier. Proceedings ... Paris: ASIC. p. 318 - 321. 
Rodrigues Jr., C. J.; Várzea, V. M. P.; Silva, M. C.; Guerra-Guimarães, L.; Rocheta, M.; Marques, D.V. (2000), Recent advances on coffee leaf rust. In: International Scientific Symposium On Coffee. 4 de dezembro de 2000. Bangalore, India, Central Coffee Research Institute. Proceedings Coffee Board. p.179193.

Sera, T.; Guerreiro, A. (1995), Correlação entre o dano de geada e outras características agronômicas em linhagens de café (Coffea arabica L.). In: Simposio Sobre Caficultura Latinoamericana, 17., 1995, San Salvador - El Salvador. Memoria de resumenes... San Salvador: PROMECAFE/ PROCAFE/Consejo salvadoreno del café. p. 27.

Varzea, V. M. P.; Rodrigues Jr., C. J.; Passo, J. E.; Palma, S. (1989), New rust genotypes and a new coffee genotype in Catimor 45. In: International Scientific Colloquium on Coffee, 13., 1989, Paipa. Proceedings ... Colômbia: ASIC. p. 745 - 748.
Varzea, V. M. P.; Rodrigues Jr., C. J.; Silva, M. C. M. L.; Gouveia, M.; Marques, D. V.; Guerra-Guimarães, L.; Ribeiro, A. (2002), Resistência do cafeeiro a Hemileia vastatrix. In: Zambolim, L. (Ed.). O Estado da arte de tecnologias na produção de café. Viçosa: UFV. cap. 8. p. 297 - 320.

Zambolim, L.; Vale, F. X. R. do.; Pereira, A. A.; Chaves, G. M. (1997), Café (Coffea arabica L.). Controle de doenças causadas por fungos, bactérias e vírus. In: Vale, F. X. R. do; Zambolim, L. (Eds.). Controle de doenças de plantas. Viçosa: UFV/Brasília - DF: Ministério da agricultura e do abastecimento. v. 1. cap. 3. p. 83 - 180.

Received: September 13, 2005; Revised: May 12, 2006; Accepted: March 20, 2007. 